\title{
Merkers vir 'n eietydse prakties-teologiese ekklesiologie
}

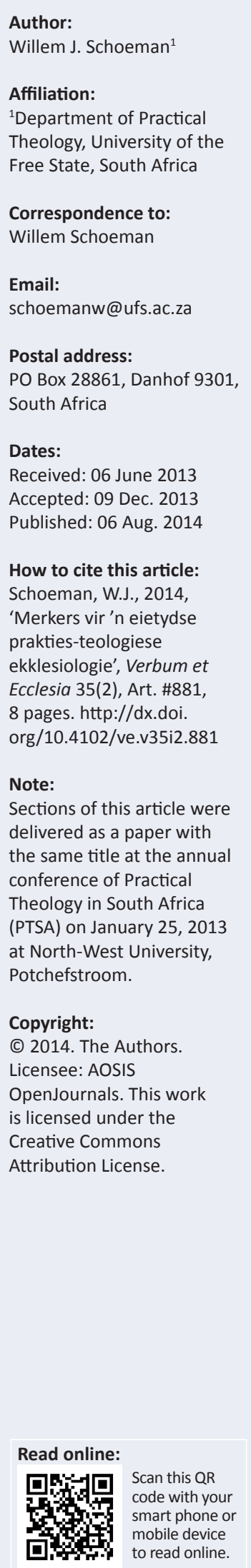

Markers for a contemporary practical theological ecclesiology. Faith communities, especially congregations, are defined and described in a number of ways. Congregations are, for example, more than the working ability of the minister or the financial contributions of its members, but these two aspects are sometimes directly or indirectly used to define a congregation. The demand for a practical theological ecclesiology requires a specific description of a congregation that is more than the abovementioned aspects. The contextualisation of the Christian faith challenge congregations to play a missional role in the community and society. Moral-ethical challenges, the lack of a critical public presence and serious social problems constitute an imperative for the reconsideration of the role of congregations. Empirical research suggests that congregations are mostly working with an 'own' internal agenda. Not enough attention, and sometimes little attention, is being paid to matters beyond the congregational boundaries. Is this a sound ecclesiology? This article aims to propose guidelines along which a relevant contextual and practical theological ecclesiology can be developed.

\section{Inleiding}

Gemeentes, as geloofsgemeenskappe, neem 'n belangrike plek in die kerk en die samelewing in. Gemeentes is draers van die evangelieboodskap en hierdie evangelie-gebeure vind altyd binne ' $n$ ' $n$ bepaalde tyd en konteks plaas. Die kontekstualisering van die Christelike geloof daag gemeentes voortdurend uit om binne die gemeenskap en samelewing 'n missionêre rol en opdrag te vervul. Gemeentes kan nie aan die eis van kontekstualisering ontsnap nie. Kontekstualisering kan positief as 'n stimulus hanteer word of gemeentes kan die slagoffer van die eis van kontekstualisering word en meer en meer irrelevant raak. Eietydse moreel-etiese uitdagings, 'n gebrek aan 'n kritiese publieke teenwoordigheid en ernstige sosiale probleme maak besinning oor die uitvoering van gemeentes se taak noodsaaklik. Empiriese navorsing dui daarop dat gemeentes meesal met 'n na-binne-gerigte agenda besig is en nie genoegsame aandag gee aan sake wat verder as die gemeentegrense strek nie. Teen dié agtergrond kom die soeke na 'n verantwoordbare en eietydse ekklesiologie op die tafel. Hierdie artikel het ten doel om riglyne te ontwikkel waarbinne 'n relevante en kontekstuele prakties-teologiese ekklesiologie ontwikkel kan word.

\section{Is 'n eietydse ekklesiologie nodig?}

Gemeente en samelewing is nie staties nie, maar ondergaan met verloop van tyd sekere ontwikkelinge en veranderinge (kyk na Dekker \& Stoffels 2001:95-107). Lidmate lewe binne 'n spesifieke omgewing en dra die eiesoortige problematiek en uitdagings van die samelewing in die wêreld van die geloofsgemeenskap in. Dit gebeur ook andersom: 'n Gemeente wat 'n verskil in 'n bepaalde gemeenskap wil maak word gedwing om ernstig kennis te neem van wat binne die gemeenskap gebeur. Dit is noodsaaklik as die gemeente relevant en hoorbaar in die gemeenskap wil wees. Dekker (1995:104-105) onderskei drie maniere waarop die samelewing die kerk binnekom:

- Kultuur kleur godsdiens, leerstellings en denkbeelde wat in die kerk aan die orde kom.

- Die plek wat die lidmate in die samelewing inneem, kom die kerk binne. Dit verwys onder andere na die rol wat die beroep, ouderdom en sosiale status van die lidmate in die gemeente speel.

- Die probleme van die samelewing kom deur middel van die lidmate die kerk binne. Werkloosheid, etiese probleme en armoede konfronteer byvoorbeeld die kerk.

Nuwe uitdagings vra nuwe en relevante antwoorde en interpretasies: '... the experience of being brought up short causes us to become aware of the interpretative activity we are taking for granted' (Osmer 2008:21). Sulke gebeure behoort gemeentes se verstaansraamwerke en aktiwiteite uit te 
daag. Hier onder word enkele voorbeelde uitgewys wat die punt 'of being brought up short' behoort te verduidelik.

Die verbruikerskultuur speel 'n belangrike rol in die samelewing en het ' $n$ bepaalde invloed op gemeentes. In 2002 het Müller en De Koker ' $n$ ondersoek na gemeentes in die ooste van Pretoria onderneem. Hulle het die volgende vraag gevra: Wat gebeur in die gemeentes, veral in die eredienste, te midde van 'n kultuur van voorspoed? Twee van hulle bevindinge, wat ook die soeke na 'n relevante ekklesiologie uitwys, kan uitgelig word:

- Die kerklike toneel is in baie opsigte vergelykbaar met een van die vlooimarkte waar die mense van die ooste van Pretoria so graag koop. Gemeentes is soos stalletjies wat teen mekaar wedywer om die beste resultate te behaal. Die gevolg is ' $n$ ongesonde kompetisie tussen gemeentes met sommige wat sleg verloor. Die kompetisiegees wat so eie is aan die voorspoedskultuur word kritiekloos deel van die kerkkultuur. Daar heers nie 'n gees van samewerking tussen kerke en gemeentes nie, maar een van wedywering (Müller \& De Koker 2002:448).

- Daar is lidmate in die ooste van Pretoria wat hulle gemeentes as wêreldvreemd beleef. Die gemeentes word as 'suksesvol' gesien, maar tog binne 'n eie, na-binnegerigte kerklike subkultuur. Dit is asof sulke gemeentes met hulle gebruike en gewoontes kommunikeer dat hulle nie omgee vir die situasie waarin hulle lidmate elke dag leef nie. Die 'sukses' wat hulle Sondae in die erediens beleef, word nie in die praktyk van die vertaal week nie (Müller \& De Koker 2002:449).

Die uitdagings wat aan 'n relevante ekklesiologie gestel word, kan met 'n tweede voorbeeld verduidelik word: die scenario waar 'n Christelike lewenstyl sigbaar en uitkenbaar in die samelewing is. Die verwagting is dat die kerk en ook gemeentes betrokke sal wees by 'n kritiese gesprek oor die waardes en norme wat in die gemeenskap nagevolg word. Die skhothane township-kultuur, byvoorbeeld, stel 'n unieke uitdaging aan die kerk. Petrus (2012) berig so hieroor:

Vla is deur die Hoërskool Brebner in Bloemfontein verbied omdat leerlinge dit op mekaar uitgooi en daarmee mors om te wys hulle kan dit bekostig. Hiermee het die gewilde township-kultuur, skhothane, waarin onder meer duur ontwerpersklere en geldnote verbrand word, sy kop in die stad uitgesteek. Van die leerlinge aan Brebner wil glo vir ander wys hulle het baie geld en kan dit bekostig om so met vla te mors. (geen bladsy beskikbaar)

Hierdie voorstedelike skool is binne die bedieningsveld van verskeie gemeentes in die stad geleë. Gemeentes wat 'n verskil wil maak, behoort hiervan kennis te neem om sodoende die skhothane township-kultuur uit te daag, of, kan ons vra, is die gemeentes net met 'n 'eie' na-binne-gerigte bediening besig?

'n Derde voorbeeld kan uitgewys word om die soeke na 'n eietydse ekklesiologie te illustreer. In sy boek Redeeming the past skryf Michael Lapsley (2012) na aanleiding van die werkswinkels wat hulle aanbied oor die gebrek aan versoening in sekere dele van die gemeenskap:
Here we were working with the South African Council of Churches that included multiracial denominations with many large, mainly white congregations, yet most white people seemed to feel little imperative as Christians or South Africans to seek reconciliation with black people. Black people who came to our workshops displayed an astonishing openness to healing old wounds, and would say, 'We're willing to reconcile, but we have no one to reconcile with.' (p. 150)

Watter rol het gemeentes in hierdie verband gespeel? Dit kan wees dat gemeentes reken versoening en geregtigheid in die gemeenskap is nie op hulle agenda nie.

Bogenoemde voorbeelde illustreer die noodsaak vir 'n soeke na 'n eietydse ekklesiologie. Gemeentes is nie eilande nie, maar juis geroep om sout en lig te wees in die omgewing waarbinne hulle bestaan (kyk byvoorbeeld na Jesus se bergrede in Matteus 5 tot 7). Die vraag sou gestel kon word: Skep gemeentes se ekklesiologie voldoende ruimte vir hulle om in die samelewing relevant te wees? Die oogmerk van hierdie artikel is om sekere merkers uit te wys wat met die ontwikkeling van 'n tydige of eietydse en relevante ekklesiologie te help. Daar behoort nie in die slaggat getrap te word om met 'n tydlose ekklesiologie te werk nie.

\section{Ekklesiologie en die gestaltes van die kerk}

Wat word met die konsep ekklesiologie bedoel? As 'n beginpunt kan gestel word dat ekklesiologie die kerk wil definieer en omskryf (kyk na Van Gelder 2000:26). Ekklesiologie verwys na die verskillende gestaltes of bestaanswyses van die kerk. Niemandt (2012:n.p.) beskryf ekklesiologie as '... a theological discipline that seeks to understand and define the church ...' Die kerk ontstaan vanuit 'n verhouding met die Drie-enige God (kyk na Burger 1999:148; Heyns 1977:67-85) en word deur God na die wêreld gestuur.

Die woord 'kerk' word op verskeie maniere verstaan. Guder (2000:14) wys byvoorbeeld na die volgende sewe moontlikhede: '... a building, an event, a policy body, a relational group, an institusionalized denomination, an organizational style, and the practice of affirming correct confessional criteria.' Smit (2008:70-71) gaan verder en wys op die volgende gestaltes van die kerk of wyses waarop die woord 'kerk' verstaan kan word:

- Kerk kan na die aanbiddende gemeenskap verwys. Gewoonlik kom gelowiges op 'n Sondag in 'n erediens bymekaar om die Here te aanbid. 'Ons gaan Sondag kerk toe', is die manier waarop hierdie verstaanswyse gewoonlik uitgedruk word. Kerk verwys hier na Sondag se erediens.

- Die plaaslike gemeente kan as die kerk verstaan word. Dit is 'n geloofsgemeenskap wat binne ' $n$ bepaalde gebied of woonbuurt gevind word.

- 'n Spesifieke denominasie, as 'n groepering van gemeentes, kan as kerk verstaan word, byvoorbeeld die Anglikaanse kerk. In hierdie geval word na die denominasie as kerk verwys. 
- 'n Ekumeniese liggaam word as 'n kerk beskou. Na so 'n groepering van kerke word na verwys as 'n kerk.

- Die kerk is ook 'n vrywillige organisasie en bestaan uit lede wat uit eie keuse gekies het om deel van die organisasie te wees. In dié geval laat kerk die klem op die organisasie of sosiale groepering val.

- Kerk kan verwys na individuele gelowiges wat op 'n informele vlak saam gegroepeer word. Die kerk as sout en lig vir die wêreld verwys na gelowiges wat só binne 'n samelewing lewe. Dit verwys na 'n sosiale kategorie met bepaalde eienskappe.

Vir die doeleindes van hierdie artikel sal die klem op die plaaslike geloofsgemeenskap of gemeente as gestalte van die kerk val. Hierdie keuse sluit nie die ander gebruike of verwysings na die kerk uit nie, maar dit gaan hier veral na 'n soeke vir die beskrywing van 'n ekklesiologie wat vir die plaaslike geloofsgemeenskap relevant is. 'The church exists first and foremost on the level of a local community. Denominational structures and church hierarchies might be important, but the missional church is a local church' (Niemandt 2012:n.p.). Die klem val dus hier op die gemeente, of plaaslike geloofsgemeenskap, as 'n gestalte van die kerk. Die plaaslike gemeente is waarskynlik die belangrikste gestalte van die kerk.

\section{Die gemeente in 'n gemeentelike ekklesiologie}

Gemeentes is belangrik, maar wat is 'n gemeente? Hoe sou hierdie plaaslike gestalte van die kerk beskryf kon word? Gemeentes kan op verskeie maniere gedefinieer en beskryf word. Gewoonlik gebeur dit dat na een of twee aspekte van die gemeentelike lewe verwys word, byvoorbeeld die finansiële posisie van die gemeente, die rol van die predikant of die sosio-ekonomiese status van die lidmate. Hierdie aspekte vorm dan, direk of indirek, die kern of uitgangspunt vir die verstaan van 'n gemeente. Die vraag na 'n praktiesteologiese ekklesiologie vereis ' $n$ bepaalde beskrywing van 'n gemeente wat wyer as net enkele van die bogenoemde aspekte van die gemeentelike lewe strek.

Gemeentes is, daarom meer as enige een van die volgende:

- Die werkvermoë van die predikant word die kern van 'n gemeente. Die plaaslike gemeente bestaan uit gelowiges wat binne' $n$ bepaalde gebied woon en waar die predikant 'n belangrike rol speel. Dekker (1995) maak die volgende kritiese opmerking oor die vorming van so 'n gemeente:

Als men het protestantse kerkelijke leven goed bestudeert kan men constateren dat ten diepste niet het territoriale, maar het dominocratische principe de inrichting van dat leven bepaalt: niet het bestaan van bepaalde kerkelijk organisatie, maar de omvang van de werkkracht en takenpakket van de predikant. (bl. 141)

Die gemeente word in samehang met en in afhanklikheid van die pligte en vermoë van die predikant gevorm en in stand gehou.
- Die finansiële bydrae van lidmate bepaal die gemeente. In hierdie geval word die begroting gebruik om die gemeente mee te definieer. Finansies speel ' $n$ groot rol in die funksionering van die gemeente: dit bepaal wie aangestel en wat gedoen kan word. Ten regte of ten onregte word 'n groot klem op die finansiële vermoë van die lidmaat en gemeente geplaas, maar kan dit 'n gemeente definieer?

- Die privatisering en individualisering van godsdiens lei daartoe dat lidmate 'n vrye keuse van assosiasie het (Heitink 2008:168-169). Gemeentes ding op die markplein mee om lidmate se betrokkenheid. Gemeentes raak op die bevrediging van godsdienstige verbruikers se behoeftes ingestel. Dit lei onvermydelik tot 'n kompetisie tussen gemeentes (Britz \& Müller 2003:6-7).

- Die gemeente kan as sosiale en kulturele vereniging beskou word. Die lede betaal hulle lidmaatskapsfooie (dankoffer) en geniet bepaalde voorregte by die vereniging. Dit lei gewoonlik tot 'n sterk klem op instandhouding en die insluiting van 'ons'-mense.

Bogenoemde aspekte word soms direk of indirek gebruik om 'n gemeente mee te definieer. Die vraag na 'n praktiesteologiese ekklesiologie vereis ' $n$ bepaalde beskrywing van 'n gemeente wat wyer strek as bogenoemde aspekte. Die uitdaging vir 'n relevante ekklesiologie is om bovermelde aspekte só met mekaar in verband te bring dat dit reg laat geskied aan wat die gemeente veronderstel is om te wees en te doen.

\section{Riglyne vanuit 'n missionale ekklesiologie}

In die soeke na die beskrywing van 'n ekklesiologie word daar meesal na die konsep 'missionale ekklesiologie' ${ }^{1}$ verwys. Niemandt (2012) omskryf die spesifieke invalshoek van 'n missionale ekklesiologie:

... missional ecclesiology does this from a missional point of view where the Church is understood as a community of witness, called into being and equipped by God, and sent into the world to testify to and participate in Christ's work. (n.p.)

Die volgende kan kortliks, onder andere na aanleiding van die dokument van die NG Kerk, as kernelemente van 'n missionale ekklesiologie uitgewys word.

In die eerste plek gaan dit oor die missio Dei as identiteit en opdrag vir die gemeente. Om deel te wees van God se sending na die wêreld is 'n wesenlike deel van die gemeente as liggaam van Christus. Die missio Dei gee betekenis en inhoud aan die missio ecclesiae. Die gemeente, as plaaslike gestalte van die kerk en primêre instrument van God se sending, maar ook die kerk as geheel en elke lidmaat daarvan, is deur God gestuur. Dit is die werk van God drie-enig. Niemandt (2012) verwoord dit soos volg:

The missional church is about congregations in this transformational field of power created by the Spirit. The church is a community created by the Spirit and derives its unique identity from this very fact. (n.p.)

1.Kyk na die dokument in die Agenda van die Algemene Sinode van die NG Kerk (2011). 
God se missie vir die gemeente bepaal die gemeentelike ekklesiologie.

'n Missionale gemeentelike ekklesiologie plaas in die tweede plek nie fokus op die gemeente nie. Die gemeentelike fokus word verbreed om die Koninkryk van God in die oog te hou. 'n Gemeentelike ekklesiologie word verruim deur die gemeente binne die raamwerk van die Koninkryk van God te verstaan, soos Niemandt (2012) aandui:

The coming kingdom is a present reality with the expectation of the future completion of God's redemptive work. The church is the community through which the kingdom is concretely manifested in history. (n.p.)

Binne die raamwerk van 'n missionale ekklesiologie is die konteks in die derde plek van groot belang. Die kerk word na die wêreld gestuur. Die feit dat die kerk altyd op die wêreld gerig is en op pad na die wêreld is, onderstreep hoe belangrik dit is om die konteks te ontleed en te verstaan. Die kerk is baie vertroud met goeie eksegese van die Bybel, maar 'n eksegetiese vaardigheid wat soms agterbly, is die analise van die konteks en kultuur.

Inkarnasie, as 'n vierde element, beteken dat die evangelie in die wêreld tuiskom. Die kruis van Christus dui op die menswording van die evangelie in hierdie wêreld. Dit het belangrike teologiese en praktiese implikasies vir die gemeentelike bediening. Gemeentes is deel van 'n geloofsgemeenskap wat hierdie evangelie herkenbaar en sigbaar maak. Hierdie feit behoort 'n wesenlike verskil aan 'n gemeentelike ekklesiologie te maak. 'A missional-incarnational ecclesiology decentres the church from a self-centred life and makes the church sensitive towards outsiders and strangers' (Niemandt 2012:n.p.). Die inkarnasie van die evangelie maak die gemeente op 'n baie spesifieke en besondere manier kontekstueel.

Binne ' $n$ missionale ekklesiologie is verhoudings binne die gemeente maar ook verhoudings na die gemeenskap, vyfdens, van groot belang. Niemandt praat in die verband van koinonia, liefde en 'n gemeenskap van liefde: '... this ultimate expression of relationality (koinonia) and love is transmitted to the whole world not as dogmas or ethical commands, but as a communion of love' (Niemandt 2012:n.p.). Die kwaliteit van gemeentelike verhoudings dra 'n missionale boodskap.

Laastens kan die rol van leierskap as 'n kenmerk van 'n missionale ekklesiologie nie misgekyk word nie. Missionale leierskap gaan oor die transformasie van mense en instellings om die missio ecclesia te kan uitvoer. Missionale leierskap rus die gemeente toe om die hele wêreld met die hele evangelie te bereik. Dit is leierskap wat transformasie bevorder.

Die bogenoemde kenmerke van 'n missionale ekklesiologie help met die ontwikkeling en bepaling van 'n gemeentelike ekklesiologie, maar gaan dit ver genoeg?'n Kritiese vraag in dié verband is die rol van ' $n$ veranderende konteks in die bepaling van 'n gemeentelike ekklesiologie. As die veranderings nie behoorlik verreken word nie, kan die ekklesiologie en gemeente, al is dit missionaal, moeilik relevant bly.

\section{Die invloed van veranderende omstandighede op 'n gemeentelike ekklesiologie}

Gemeentes leef en werk sonder twyfel binne 'n dinamiese omgewing. Verandering is deel van hierdie werklikheid. Die omgewing waarbinne 'n gemeente leef en dien, verander gedurig. Die wêreld van vandag is nie dieselfde as die wêreld van 10 of 20 jaar gelede nie. Die wêreld het nie net deur middel van die tegnologiese ontwikkelinge van die afgelope tyd plat geword nie, maar het verder ook vloeibaar geword (Joubert 2012:2).

Die kontekstualisering van die Christelike geloof daag gemeentes uit om binne die gemeenskap en samelewing 'n betekenisvolle rol te vervul. Sou'n gemeentelike ekklesiologie as 'n statiese konsep verstaan kon word?

Verandering in die konteks daag nie net gemeentelike prosesse en programme uit nie, maar op'n meer fundamentele vlak daag die verandering in konteks ook die gemeentelike identiteit uit. Die vraag is nie net wat die gemeente doen (projekte en programme) nie, maar ook wie die gemeente is (identiteit)? Veranderings aan die konteks beteken dat die gemeente in die lig van die Woord en onder leiding van die Heilige Gees moet bepaal hoe om by veranderende omstandighede aan te pas (Schoeman 2002:219). Identiteit en konteks is in interaksie met mekaar en 'n herontdekte identiteit lei noodwendig tot nuwe prosesse en programme.

Wat is die verband tussen verandering en 'n gemeente se identiteit en bediening? Die volgende prosesse kan in hierdie verband uitgewys word (kyk na Schoeman 2002:219-220):

- 'n Gemeente se identiteit word deur haar storie en geskiedenis bepaal. 'n Te sterk klem op die verlede lei tot 'n instandhoudingsbediening wat beheer beklemtoon.

- Die hede of huidige konteks beïnvloed die gemeente se identiteit. Dit hang saam met politieke, ekologiese, demografiese en sosiale faktore. 'n Oormatige fokus op die hede lei tot ' $n$ bediening wat so markgeoriënteerd raak dat dit vervlak tot ' $n$ bediening wat net op behoeftebevrediging ingestel is.

- Die gemeente se visie op die toekoms, ideale en roepingsbewustheid speel ook ' $n$ rol in die vorming van 'n gemeente se identiteit. 'n Te groot klem op die toekoms gaan by die verlede se storie en die huidige situasie verby en verwaarloos die gemarginaliseerdes in hulle nood. Geen aandag word dan byvoorbeeld aan sosiale onreg gegee nie.

Uit bogenoemde beskrywing is dit duidelik dat 'n gemeentelike ekklesiologie nie 'n statiese konsep kan wees nie. 'n Relevante ekklesiologie is daarom nooit tydloos nie. Stagnasie hou 'n groot gevaar in, naamlik dat daar in bepaalde eensydighede vasgeval kan word en dat 'n gemeente mettertyd gewoon irrelevant kan raak. Die gemeente word dan 'n museum waar waarnemings oor hoe sake in die verlede verloop het en dinge gedoen is, gedoen 
kan word. Dit is ' $n$ wesenlike gevaar en bepaalde hindernisse kan uitgewys word wat daartoe kan bydra dat gemeentes stagneer as daar met 'n tydlose ekklesiologie gewerk word.

\section{Hindernisse in die soektog na 'n eietydse ekklesiologie}

Gemeentes sit soms in 'n kultuur van instandhouding vasgevang. In die geval van die NG Kerk is meer as $50 \%$ van die gemeentes óf met 'n stryd om oorlewing óf met instandhouding besig (Schoeman 2012). In die soektog na 'n weg uit die stryd om oorlewing word daar nie na 'n eietydse en relevante ekklesiologie gesoek nie. Gemeentes soek nie altyd die sin vir hulle bestaan in ' $n$ missionêre ekklesiologie nie, maar meer as 'n derde van NG Gemeentes sit vas in 'n ou sendingparadigma (Schoeman 2012). Verskeie faktore kan uitgewys word as hindernisse in die soektog na ' $n$ eietydse ekklesiologie.

Eerstens is daar 'n sterk kulturele verbintenis tot gemeentewees. Gemeentes word as die bewaarder en bewaker van 'n bepaalde taal en kultuurgroep se waardes beskou. Alles behoort op 'n eiesoortige manier of in 'n moedertaal gedoen word. Die tradisionele wyse van aanbidding speel 'n sterk rol. Die kerk en gemeentes bly 'n ruimte waar taal en kultuur bewaar kan word: '... the churches are the most secure; they are the only space in which Afrikaners can be left alone to be white and Afrikaans without interference ...' (Jansen 2009:35). Giliomee (2013) wys daarop dat die NG Kerk weens bepaalde historiese redes '... 'n kerk geword het wat feitelik net wit Afrikaanssprekendes bedien het'. Taal en kultuur word ' $n$ hindernis in die ontwikkeling van 'n verantwoordbare en relevante ekklesiologie, want dit sluit af en sluit uit.

Tweedens is gemeentes vir 'n baie lang tyd rondom baie spesifieke geografiese grense saamgestel en gevorm. Tot en met die Algemene Sinode van die NG Kerk van 1992 is lidmaatskap van die kerk net binne die duidelik omskrewe grense van 'n gemeente toegelaat. Daarna kom 'n groter openheid om lidmaatskap oor gemeentegrense toe te laat. Die geografiese nalatenskap van die praktyk leef nog sterk in die NG Kerk. Die geografiese agtergrond tot gemeentevorming verswak die geloofsverbintenis van lidmate tot 'n geloofsgemeenskap. Gemeentes maak op straatadresse staat om 'n lidmaatskapverbintenis te bepaal en nie op 'n geloofsverhouding nie.

Teenoor die geografiese koppeling van lidmate aan 'n bepaalde gemeente staan, in die derde plek, 'n verbruikersmentaliteit en markmentaliteit (kyk na Müller \& De Koker 2002). Lidmaatskap word beskou as die keuse van 'n verbruiker om die beste produk te kies. Dit lei daartoe dat gemeentes op die vrye mark om die aandag en lojaliteit van verbruiker-lidmate meeding. Hoe beter die gemeente bemark word, hoe sterker word die gemeente, en groei vind ten koste van swakker en minder bemarkbare gemeentes plaas (kyk na Britz \& Müller 2003:6-7). Dié tipe ekklesiologie werk meer met markkragte as met geloofsverbintenisse van lidmate aan 'n bepaalde gemeente. Die klem val op 'n funksionele ekklesiologie: dit wat werk, is reg vir die gemeente.

Vierdens kan die posisie van die predikant binne die gemeente as 'n hindernis uitgewys word. Die voltydse predikant speel 'n belangrike rol in die gemeente. Die vermoë van die gemeente om op 'n sekere vlak te funksioneer, word baie keer bepaal deur dit waarvoor die predikant kans sien en wat hy of sy kan doen. Die klem val op die vaardighede van die predikant. Hoe meer effektief en beter die predikant sy of haar rol vervul, hoe beter is dit vir die gemeente. Dat 'n predikant ' $n$ belangrike rol in 'n gemeente speel, kan nie ontken word nie, maar kan nie so 'n beslissende rol speel nie. Die teendeel van die argument sou wees dat klein gemeentes sonder 'n voltydse predikant nie volledig gemeente kan wees nie. Die tipe argument hou ernstige implikasies vir 'n gemeentelike ekklesiologie in.

'n Laaste hindernis wat uitgewys kan word, is die rol en plek wat die erediens binne die gemeentelike ekklesiologie inneem. Die erediens neem ongetwyfeld 'n sentrale plek in die verstaan van 'n gemeente in; dit is waarskynlik die belangrikste weeklikse byeenkoms van 'n gemeente. Die gevaar bestaan egter dat ' $n$ gemeente slegs in terme van die erediensgebeure verstaan word. Gemeentewees behels meer as net die erediens. In die geval van 'n vakante gemeente word soms slegs van afloshulp of konsulente gebruik gemaak. Die persepsie bestaan dat solank daar Sondag 'n erediens gehou word, dit met die gemeente en die lidmate goed gaan. Die belangrike vraag in terme van 'n relevante ekklesiologie is: Wat is die plek van die erediens in die gemeente en watter rol behoort dit in die beskrywing van die totale gemeentelike ekklesiologie te speel, veral in terme van kritiese vraagstukke in die wyer gemeenskap?

Empiriese navorsing dui daarop dat gemeentes meesal met 'n 'eie', interne agenda besig is. Hulle skenk nie genoegsame aandag nie - soms weinig aandag - aan sake wat verder as die gemeentegrense strek (Schoeman 2010:123). Bogenoemde hindernisse behoort in die ontwikkeling van 'n relevante ekklesiologie verreken te word.

\section{Moontlike merkers vir 'n eietydse ekklesiologie}

Die breë raamwerk vir 'n ekklesiologie is getrek. Daar bestaan 'n redelike konsensus oor die elemente van die raamwerk. Die soeke is egter na 'n eietydse ekklesiologie wat nou in die kontemporêre samelewing vir gemeentes relevant is. Vanuit die huidige Suid-Afrikaanse konteks is die vraag: Wat is die kritiese elemente waaraan gemeentes nou aandag moet gee? Wat is nie opsioneel in die ontwikkeling van 'n eietydse ekklesiologie nie? Aan die begin is verwys na drie probleme of uitdagings wat gemeentes tans uitdaag: 'n verbuikerskultuur, die navolging van Christelike waardes in die gemeenskap en die soeke na versoening binne 'n verdeelde samelewing. 
Daar is verder gewys op hindernisse in die soeke na 'n eietydse ekklesiologie. Dit is faktore wat gemeentes verhinder om werklik hulle roeping of taak uit te leef. Die soeke is na 'n relevante identiteit en roeping vir elke gemeente. Te gou word daar na projekte en programme gesoek om kits- of populêre veranderinge te bewerk. Die dieper vraag lê op die vlak van identiteit en roeping en nie in die eerste plek in die soeke na 'n paar nuwe projekte of programme nie. Dit gaan nie oor aksiestappe nie, maar oor riglyne of merkers waarlangs ' $n$ reis onderneem moet word. Die ontwikkeling van 'n ekklesiologie is baie meer ' $n$ reis as 'n projek. Dit is ' $n$ uitdaging om weg te beweeg van '... 'n teologie op die lyntjie en op die middel' (Müller 2007:510). Dit is stippellyne in die pad wat 'n moontlike koers vir gemeentes aandui waarop 'n relevante en eietydse ekklesiologie gekarteer kan word.

In die eerste plek ontstaan en groei die missio ecclesia vanuit die missio Dei. Die begronding van enige ekklesiologie bly in die verhouding met die Drie-enige God gevestig, soos Bosch (1991; kyk ook na Guder 2000:15-23) dit verwoord:

Mission is, primarily and ultimately, the work of the Triune God, Creator, Redeemer, and Sanctifier, for the sake of the world, a ministry in which the church is privileged to participate. (p. 392)

Die missio Dei werk op die vlak van die identiteit en ook (daarna) op die vlak van'n strategie vir die gemeente. Die missio Dei word die DNS (DNS deoksiribonukleïensuur) van missio ecclesia. 'As an organism holds together, and each cell understands its function in relation to its $D N A$, so the church finds its reference point in its build-in mDNA' (Hirsch 2006:76). Gemeentes het nodig om vanuit hulle identiteit te lewe, om as skepping van die Gees teenwoordig te wees. Dit is nodig dat gemeentes daar is en minder doen of 'hard' werk. Die bestaanswyse van die gemeente is in die gemeente se $m D N A$ gewortel. In die kern van die gemeente se verstaan en wees is ' $n$ diep gewortelde verhouding met die Vader, Seun en Heilige Gees. Vanuit die $m D N A$ ontwikkel en groei die lewensstrategie van die gemeente met die oog op die wêreld. 'n Enkele voorbeeld: Die lewe van die gemeente getuig van die versoenende werk van God wat die onbegrensde versoening tussen mense moontlik maak, want dit is deel van die gemeente se $m D N A$.

Die vraag kan gestel word of gemeentes hulle huidige konteks ernstig genoeg opneem? Gemeentes funksioneer baie keer soos eilande, geïsoleer van die wêreld, en word maar net 'n weeklikse onvlugtingsentrum uit 'n moeilike wêreld. Die tweede merker is daarom die soeke om radikaal kontekstueel te wees, een van die kenmerke van 'n postfoundational praktiese teologie (Müller 2005:77, 2011). Die vrae en worstelinge van die gemeenskap word (is?) ook die vrae en worstelinge van die gemeente. Müller (2005) verwoord dit soos volg:

On the contrary, the postfoundationalist approach forces us to firstly listen to the stories of people struggling in real life situations. It does not merely aim to describe a general context, but we are confronted with a specific and concrete situation. (p. 76)

Na hierdie spesifieke en konkrete situasie moet in die eerste plek geluister word. Op 'n eerste vlak gaan dit oor die algemene verhale wat in die gemeenskap gedeel word. Op 'n volgende vlak word verhale net binne ' $n$ ruimte van vertroue gedeel. Meylahn (2012) stel dit soos volg:

In listening to this second layer of narratives the cracks, discrepancies and wounds of the dominant common language is revealed. The unheard, unspoken, hidden narratives emerge under the dominating umbrella of the common language. (p. 57)

Gemeentes begin om radikaal kontekstueel te word as daar ruimte is om hierdie verhale te vertel en te hoor.

Die luisterproses behoort 'n stap verder geneem te word. Inkulturasie gaan oor 'n leerproses om vanuit die Christelike geloofstradisie met ' $n$ nuwe en veranderende kultuur verbind te word (Heitink 2008:44). Aan die een kant gebeur dit deur gelowiges vir hulle daaglikse lewe in die samelewing toe te rus. Aan die anderkant gaan dit oor die taak van die kerk teenoor die samelewing: '... het profetisch spreken, de voorbede, de diaconie en in grenssituasies de burgerlijke ongehoorzaamheid ...' (Heitink 2008:75). Hierdie aksies veronderstel ' $n$ intensiewe en luisterende betrokkenheid van die gemeente in die samelewing. Mwambazambi (2011) wys daarop dat kontekstualisering een van die groot uitdagings vir 'n 'Afrika' ekklesiologie is.

Derhalwe die vraag of gemeentes nog ernstig opgeneem word en of gemeentes se getuienis nog geglo word? 'n Derde merker is 'n soeke na 'n geloofwaardige gemeentelike lewe. Dit gaan oor gemeentes wat met Christelike integriteit lewe en wat sodanig raakgesien word. Die geloofsgemeenskap is 'n unieke nuwe skepping van die Gees (Theron 1978:73) en nie '... maar net die religieuse variant van natuurlike groepe, bewegings, sosiale strata en wat nog meer nie' (Smit 2008:76). Die geloofsgemeenskap is in dié sin ' $n$ 'vreemde' gemeenskap of, in die woorde van Osmer (2008:191), 'n kontra-gemeenskap: '... congregations embody in their internal relationships and their relations with their neighbors an alternative to power and authority as conventionally practiced in the world.' Die gemeente verteenwoordig ' $n$ Christelike alternatief en dit behoort te help om 'n unieke of plaaslike ekklesiologie te ontwikkel. 'n Geloofwaardige gemeentelike lewe lei tot 'n etiese verantwoordbare lewenstyl. Dit het sekere etiese implikasies, veral op die publieke terrein, want dit gaan ook oor die transformasie van die gemeenskap. 'There is a rediscovery of missional ethics, especially as a matter of counter cultural witness' (Niemandt 2012:n.p.). 'n Eietydse ekklesiologie vra kritiese etiese vrae.

Vierdens behoort die verbondenheid aan 'n geloofsgemeenskap herbeskryf te word. Die geykte definisies van lidmaatskap word binne 'n veranderende konteks uitgedaag. Lojaliteit en betrokkenheid is nie meer dieselfde as 'n dekade of twee gelede nie. Groter keusevryheid en vrywillige assosiasie vra ruimte vir verbintenisse op verskeie vlakke in die gemeente. De Roest (2005:43-53) wys op drie modelle waarop die verbintenis beskryf kan word. Die eerste model is dié van totale betrokkenheid waar die gemeente 'n vangnet en lidmaatskap 'n lewenslange verbintenis is. Die 
tweede model beskou die gemeente as herberg en dit vereis gedeeltelike betrokkenheid waar die gemeente as gas besoek word. Die derde model beskryf die gemeente as 'n tempel, die gemeente word op die kruispunte van die lewe besoek, byvoorbeeld tydens ' $n$ begrafnis. Die drie modelle wys op die problematiek van lidmaatskap en betrokkenheid by die gemeente. Teenoor 'n geringe deelname staan betrokkenheid of wat Heitink (2008:154) 'participatie' noem. 'n Gemeente sonder lidmate is gedoem, maar hoe moet dit verstaan word? Lidmaatskap moet ruimte laat vir 'n kern met 'n hoë toelatingsdrempel en betrokkenheid, maar ook vir verdere afstand wat slegs die moontlikheid skep om 'n toeskouer en nie 'n aktiewe deelnemer nie te wees (kyk na Heitink 2008:175-181). 'n Enkelmodel vir betrokkenheid gaan in die huidige tydsgewrig moeilik werk, daarom '... zullen meer oog moeten krijgen voor verschuiveningen in betrokkenheid, samehangend met leeftijd, gezinsituatie, levenservaring en maatschapelijke verantwoordelijkheden' (Heitink 2008:188). De Roest (2005:184) wys daarop dat die metafoor van die teater dalk kan help. Dit laat ruimte vir betrokkenheid en deelname, regie deur die leierskap en kreatiwiteit, maar dit laat ons ook net met toeskouers. ' $n$ Relevante ekklesiologie word uitgedaag om kreatief oor lidmaatskap en betrokkenheid te dink.

Gemeentes en denominasies gaan, vyfdens, al hoe meer gedwing word om saam te werk. Aan die een kant gaan dit in kleinerwordende gemeentes oor demografiese druk om saam te werk, om eredienste en take saam aan te pak. Aan die ander kant noodsaak die omvang van gemeenskapsuitdagings dat gemeentes saamwerk. Gemeentes kan nie een-een by 'n disfunksionele plaaslike owerheid opdaag nie. 'n Gesamentlike ekumeniese stem dra veel groter gewig. Ekumeniese verhoudings en netwerke tussen geloofsgemeenskappe gaan 'n al hoe belangriker rol speel. Die katolositeit van gemeentewees speel hierin 'n groot rol. 'I have come to conclude that in times of serious adaptive challenge, the church too will maximize its survival by decentralizing, spreading and multiplying' (Hirsch 2006:207). Die reis kan nie alleen as 'n enkele gemeente of denominasie aangepak word nie. Binne 'n eietydse ekklesiologie word nuwe netwerke en verhoudings oor grense heen ontdek en ontgin.

Laastens word unieke en nuwe uitdagings aan die leierskap van geloofsgemeenskappe gestel. Leierskap vra 'n sekere onderskeidingsvermoë: '[d]iscernment as the first act in mission' (Niemandt 2012:n.p.). Leierskap gaan oor die skep van hoop, hoop vir die leier, maar ook vir die gemeente (Müller 2002:736). Ruimtes behoort geskep te kan word om op nuwe en kreatiewe maniere te kan hoop. Dit vra 'n kreatiewe onderskeidingsvermoë van die leierskap wat met God in die wêreld op pad is. 'This kind of discernment is a communion imagination that participates in the movement of the Spirit in the world' (Niemandt 2012:n.p.). Die vorm van missionêre leierskap vra 'n nuwe styl van leierskap en ook 'n ekklesiologiese ruimte om dit te kan doen, soos Müller (2002) argumenteer:

Not only new styles are necessary, but new organisational structures for churches and congregations must be developed, so that the leader can be a guardian of hope, but at the same time be an ordinary human being in need of care. (p. 744)

Die leierskap van 'n gemeente is reisgenote wat ruimtes oopmaak sodat daar met integriteit na die verhale van die gemeente en gemeenskap geluister kan word (kyk ook na Meylahn 2012:53-56). Hierdie vorm van leierskap is wesenlik deel van 'n relevante ekklesiologie.

\section{Gevolgtrekking}

Die bogenoemde merkers vir 'n relevante ekklesiologie dui 'n rigting aan waarlangs gesoek moet word, dit daag die onderskeidingsvermoë van gemeentes en die leierskap uit. Hierdie prakties-teologiese onderskeidingstaak is nie eenvoudig nie. Dit vra '... eerder om die spanning in al sy kompleksiteit en paradoksaliteit te verwoord en sodoende die moontlikheid te skep dat die lig van die Evangelie daarop kan val' (Müller 2007:513). Die ontwikkeling van 'n eietydse ekklesiologie is 'n unieke maar komplekse taak. Die grootste uitdaging vir gemeentes is waarskynlik die soeke na ' $n$ missionêre en kontekstuele teenwoordigheid binne die gemeenskap en samelewing.

\section{Erkenning Mededingende belange}

Die outeur verklaar dat hy geen finansiële of persoonlike verbintenis het met enige party wat hom in die skryf van hierdie artikel nadelig kon beïnvloed nie.

\section{Literatuurverwysings}

Agenda van die Algemene Sinode, 2011, Missionale ekklesiologie, bl. 130-141.

Bosch, D.J., 1991, Transforming mission: Paradigm shifts in theology of mission, Orbis Books, Maryknoll, NY.

Britz, J.J. \& Müller, J.C., 2003, "n Bemarkende en bemarkbare kerk', Praktiese Teologie Suid-Afrika 18(2), 1-12.

Burger, C.W., 1999, Gemeentes in die kragveld van die Gees, CLF-Drukkers, Bloemfontein. Dekker, G., 1995, Als her getij verloopt ..., Ten Haave, Baarn.

Dekker, G. \& Stoffels, H.C., 2001, Godsdienst en samenleving, 5de hersiene druk, Uigeverij Kok, Kampen.

De Roest, H., 2005, En de wind steekt op! Kleine ecclesiologie van de hoop, Meinema, Zoetermeer.

Giliomee, H., 2013, Het apartheid by die kerk begin? Litnetakademies, besigtig op $14 \mathrm{Me}$ 2013, by http://www.litnet.co.za/Article/hermann-giliomee-het-apartheid-by-diekerk-begin

Guder, D.L., 2000, The continuing conversion of the church, William B. Eerdmans Publishing Company, Grand Rapids, MI. PMCid:PMC110582

Heitink, G., 2008, Een kerk met kakrakter: Tyd voor heroriëntatie, 2de druk, Kampen, Uitgeverij Kok.

Heyns, J.A., 1977, Die kerk, N.G. Kerkboekhandel, Pretoria.

Hirsch, A., 2006, The forgotten ways: Reactivating the missional church, Brazos Press, Grand Rapids, MI.

Jansen, J.D., 2009, Knowledge in the blood: Confronting race and the apartheid past, Stanford University Press, Stanford.

Joubert, S., 2012, 'not by order, nor by dialogue: The metanoetic presence of the kingdom of God in a fluid new world and church', inaugural delivered as extraordinary professor at the Faculty of Theology, University of the Free State, 09 Mei 2012.

Lapsley, M., 2012, Redeeming the past: My journey from freedom fighter to healer, Orbis Books, New York.

Meylahn, J-A., 2012, Church emerging from the cracks: A church in, but not of the world, Sun Press, Stellenbosch.

Müller, J.C., 2002, “'Butterfly-leadership": Stories of hope for church leaders', Verbum et Ecclesia 23(3), 736-745.

Müller, J.C., 2005, 'A postfoundationalist, Hiv-positive practical theology', Praktiese Teologie Suid-Afrika 20(2), 72-88. 
Müller, J.C., 2007, 'Lente in die teologie: 'n Opwindende ligstraal van hoop vir die kerk', Verbum et Ecclesia 28(2), 509-523.

Müller, J.C., 2011, 'Postfoundational practical theology for a time of transition', HTS Teologiese Studies/ Theological Studies 67(1), Art. \#837, 5 pages. http://dx.doi. org/10.4102/hts.v67i1.837

Müller, J.C. \& De Koker, W., 2002, 'Spiritualiteit te midde van 'n kultuur van voorspoed: 'n Fokus op die Ooste van Pretoria', Verbum et Ecclesia 23(2), 432-451.

Mwambazambi, K., 2011, 'A missiological refection on African ecclesiology', Verbum et Ecclesia 32(1), Art. \#482, 8 pages. http://dx.doi.org/10.4102/ve.v32i1.482

Niemandt, C.J.P., 2012, 'Trends in missional ecclesiology', HTS Teologiese Studies/ Theological Studies 68(1), Art. \#1198, 9 pages. http://dx.doi.org/10.4102/hts. v68i1.1198

Osmer, R., 2008, Practical theology: An introduction, W.B. Eerdmans, Grand Rapids, MI.

Petrus, D., 2012, 'Leerlinge mors glo met vla om te spog', Die Volksblad, 27 Oktober, besigtip op 13 Desember 2012, by www.volksblad.com
Schoeman, W.J., 2002, "n Prakties-teologiese basis teorie vir gemeente-analise", D.Th.-proefskrif, Departement Praktiese Teologie, Universiteit van die D.Th.-pro
Vrystaat.

Schoeman, W.J., 2010, 'The congregational life survey in the Dutch Reformed Church: Identifying strong and weak connections', Ned Geref Teologiese Tydskrif 51(3/4), 114-124.

Schoeman, W.J., 2012, 'The involvement of a South African church in a changing society', Verbum et Ecclesia 33(1), Art. \#727, 8 pages. http://dx.doi.org/10.4102/ ve.v33i1.727

Smit, D.J., 2008, 'Oor die kerk as unieke samelwingsverband', in N. Koopman (red.), Geloof en die openbare lewe: Versamelde opstelle 2, bl. 69-81, Sun Media, Stellenbosch.

Theron, P.F., 1978, Die ekklesia as kosmies-eskatologiese teken, NG Kerkboekhandel, Pretoria.

Van Gelder, C., 2000, The essence of the church: A community created by the Spirit, Baker Books, Grand Rapids, MI. 